Available online on 15.01.2018 at http://jddtonline.info
Journal of Drug Delivery and Therapeutics
Open Access to Pharmaceutical and Medical Research
$\begin{gathered}\text { 2011-18, publisher and licensee JDDT, This is an Open Access article which permits unrestricted non- } \\ \text { commercial use, provided the original work is properly cited }\end{gathered}$

Open 2 Access

Review Article

\title{
PHYTOSOME: MOST SIGNIFICANT TOOL FOR HERBAL DRUG DELIVERY TO ENHANCE THE THERAPEUTIC BENEFITS OF PHYTOCONSTITUENTS
}

\author{
Bhuwanendra Singh $^{1 *}$, Rajendra Awasthi ${ }^{2}$, Arshad Ahmad ${ }^{3}$, Asif Saifi $^{4}$ \\ ${ }^{1}$ Department of Pharmacognosy, NKBR College of Pharmacy \& research Centre Meerut, Uttar Pradesh \\ ${ }^{2}$ Department of Pharmaceutics, NKBR College of Pharmacy \& research Centre Meerut, Uttar Pradesh \\ ${ }^{3}$ Department of Pharmaceutical Chemistry, Shri Gopichand College of Pharmacy Baghpat, Uttar Pradesh \\ ${ }^{4}$ Department of Pharmaceutics, Shri Gopichand College of Pharmacy Baghpat, Uttar Pradesh
}

\section{ABSTRACT}

Traditional medicinal system relies on the knowledge and clinical expertization of physicians to regulate the indigenous medicinal system for the sake of well being to humans. Considering the bioavailability issues of phytoconstituents, in this review, we have focused on the various aspects of phytosomes in drug delivery. Phytosome technology is used to enhance the absorption of poorly absorbed lipid soluble active constituents from the herb extracts. So, the article covers a brief introduction of phytosomes, their method of development along with its formulation and evaluation parameters such FTIR, NMR etc. Different types of dosages forms are described in the review, merits and demerits are also discussed along with diagrammatic representation of phytosome development technique. So, the article is the direction for future research to increase the absorption of phytoconstituents.

Key words: Bioavailability, FTIR, lipid, NMR, niosomes, phytoconstituents

Article Info: Received 23 Nov, 2017; Review Completed 13 Jan, 2018; Accepted 14 Jan, 2018; Available online 15 Jan, 2018

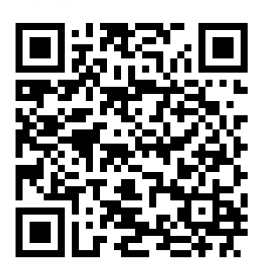

Cite this article as:

Singh B, Awasthi R, Ahmad A, Saifi A, Phytosome: most significant tool for herbal drug delivery to enhance the therapeutic benefits of phytoconstituents, Journal of Drug Delivery and Therapeutics. 2018; 8(1):98-102

DOI: http://dx.doi.org/10.22270/jddt.v8i1.1559

*Address for Correspondence

Dr. Bhuwanendra Singh, Department of Pharmacognosy, NKBR College of Pharmacy \& research Centre Meerut, Uttar Pradesh, India. Email ID: bhuwanendrasingh14@gmail.com, Contact: +91-9307634342

\section{INTRODUCTION}

Traditional medicines rely on the basis of knowledge and clinical experience of the practitioners for indigenous systems of medicine. Historically, many infectious diseases have been treated with the help of herbals. The traditional medicine is increasingly solicited through the traditional practitioners and herbalists in the treatment of infectious diseases. Among the remedies used, plant drugs constitute an important part. Current status of scientific investigations has highlighted the importance and the contribution of many plant families, i.e. Asteraceae, Liliaceae, Apocynaceae, Solanaceae, Caesalpinaceae, Rutaceae, Piperaceae, polypodiaceae ${ }^{1}$. From the very beginning, the most important parameter is solubility and absorption to increase the bioavailability of phytoconstituents to obtain more efficacies of the herbal drugs. It has been observed that most of the therapeutically active plant constituents such as the flavonoids and terpenoids, aglyconglycosides are of highly polar in the nature hence they are water soluble molecules. Thus, these are poorly absorbed due to their poor lipid solubility. Poor absorption might be due to their large molecular size which cannot absorb by passive diffusion. This limits their ability to pass across the lipid-rich biological membranes and thus resulting in poor bioavailability. There are several techniques available to overcome these problems, viz cosolvents, inclusion of solubility and bioavailability enhancers, structural modification and entrapment with lipophilic carriers ${ }^{2-8}$. Although even standardized plant materials having low solubility in the 
lipids or possess highly polar nature to assimilate as lipid profile.

A new approach named as phytosome is developed which indicates like as "plant" and "cell" [phyto means plant and some means cell like] ${ }^{9-11}$. The phytosome technology, developed by Indena S.P.A. in Italy, markedly enhances the bioavailability of selected phytomedicines, by incorporating phospholipids into standardized extracts and so vastly improve their absorption and utilization ${ }^{12}$. These novel preparations make polar phytocells to obtain highly lipid compatible molecular complexes with enhanced absorption and bioavailability. Different chemical constituents obtained from medicinal plants are water soluble phytoactive such as flavonoids, glycosides, terpenoids are delivered using phytosome technique. Because of the water soluble nature, herbal extract lipophilic outer layer phytosomes have better absorption and can show better bioavailability profile than the conventional herbal extracts containing dosage form. These are produced by a process whereby the standardized plant extract or its constituents are bound to phospholipids, mainly phosphatidylcholine, producing a lipid compatible molecular complex formation of chemical bonds between phosphatidylcholine molecule and phytoconstituent produces better stability profile ${ }^{6}$. It is laterally meant as a phytolipids delivery system ${ }^{9}$ also known as herbosomes ${ }^{10}$. It is a newly introduced patented technology ${ }^{13}$, which forms a bridge between the convectional drug delivery system and novel drug delivery system for incorporating standardized phytoextracts or water soluble phytoconstituents into phospholipids to produce lipid compatible molecular complexes to obtain greater absorption and bioavailability to acquire the higher therapeutic effects of poorly absorbed water soluble phytoconstituents. Thus, most useful application of phytosomes is the absorption of drugs in the form of reversible complexes with phospholipids, which proved their higher and long lasting anti-inflammatory and vasokinetic activities due to complexation of active ingredients with phospholipids than those observed after administration of the same amount of substance in free form ${ }^{9-13}$.

\section{Formulation approach}

Phytosomes are the reaction product of a stoichiometric amount of phospholipid ( $\alpha$-Lysophosphatidylcholine, $\alpha$ phosphatidylcholine) and standardized plant extract in the presence of a solvent which is incapable of acting as a proton donor (aprotic solvent). $\alpha$ lysophosphatidylcholine, $\alpha$-phosphatidylcholine, $\alpha$ phosphatidylethanolamine, $\alpha$-phosphatidic acid are the most commonly used as phospholipid with herbal standardized plant extracts. $\alpha$-lysophosphatidylcholine is a bifunctional chemical constituent in which phosphatidyl fraction is lipophilic in nature which denotes the head of the bifunctional compound and the hydrophilic choline fraction is the tail of the bifunctional compound. Thus, choline part of $\alpha$ lysophosphatidylcholine bounds to the hydrophilic phytoconstituents, while the lipid soluble phosphatidyl part join the choline bound complex. So, it leads to form a phyto-phospholipid complex to enhance lipid solubility. A chemical bond plays a vital role to bind the choline head with polar phytoconstituents. Thus, the phytosomes technique produces minute spheres or tiny cells, which helpful in the protection of the active phytochemical constituent from destruction by gastric microenvironment ${ }^{14}$.

Development and formulation of phytosomes take place by taking one molecule of any bifunctional chemical compound such as $\alpha$-lysophosphatidylcholine, phosphatidylcholine, phosphatidylethanolamine, $\alpha$ phosphatidic acid, with one molecule of active plant constituent which has a water soluble chemical class for example flavonoids, terpenoides, or aglycon glycosides in a solvent which is incapable acts as proton donor i.e. aprotic solvent, viz dioxane, acetone, acetonitrile, DMF, DMSO. As a result isolation of complexes takes place by precipitation with spray drying. The most preferable ratio of phospholipid to phytoconstituents is $1: 1$. phospholipids generally used are given here such as $\alpha$ phosphatidylcholine, $\alpha$-phosphatidylethanolamine, $\alpha$ phosphatidyl-L-serine, $\quad \alpha$-phosphatidylinositol, $\quad \alpha$ phosphatidic acid, $\alpha$-phosphatidyl-DL-glycerol, $\alpha$ lysophosphatidylcholine, sphingomyelin, cardiolipin but most commonly used is soy lecithin (Glycine max) and phosphatidylcholine ${ }^{15,16}$. Illustration of the development of phytosome is shown in the Figure 1.

\section{Characterization of phytosomes}

To confirm the complex formation between phospholipids and herb constituents, spectroscopic evaluation, for example, FTIR and $1 \mathrm{HNMR},{ }^{13} \mathrm{CNMR}$ to reveal the that molecules of the phytoconstituents are bonded to phospholipid fraction by means of a chemical bond are carried out 17, 18 while evaluation of drug content can be done by HPLC ${ }^{19}$ entrapment efficiency of the drug by phytosomes can be evaluated by ultracentrifugation technique ${ }^{20}$. Visualization of phytosomes can be done using transmission electron microscopy (TEM) and scanning electron microscopy (SEM) ${ }^{21}$. Thermal analysis can be done using differential scanning calorimetry ${ }^{22-24}$ Vesicle size and zeta potential are determined by dynamic light scattering which uses a computerized inspection system and photon correlation spectroscopy ${ }^{25-26}$. Surface tension activity measurement of drug in aqueous solution can be measured by the ring method Du Nouy ring tensiometer 27. 


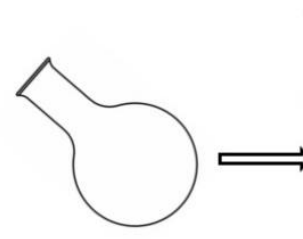

Solvent in RBF of rotary film evaporator (Aprotic Solvent viz dioxane, acetone, acetonitrile, DMF, DMSO)

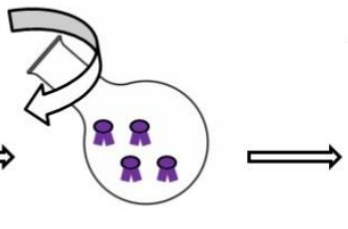

Addition of a bifunctional chemical constituent ( $\alpha$-Lysophosphatidylcholine, Phosphatidylcholine, Phosphatidylethanolamine, $\alpha$-Phosphatidic Acid)

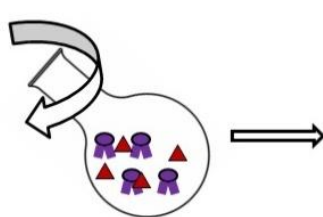

Addition of water soluble phytoconstituent (flavonoids, terpenoides, aglycon glycosides etc.)

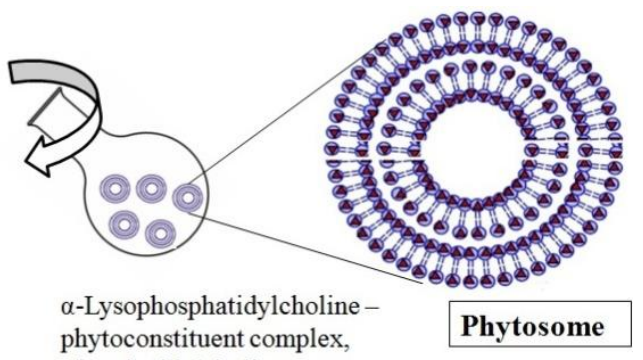
phytoconstituent complex, phosphatidylcholine-

phytoconstituent complex, phosphatidylethanolaminephytoconstituent complex $\alpha$-Phosphatidic Acidphytoconstituent complex

Figure1. Illustration of Phytosome development, evaluation and characterization

Table1. Details of the investigations based on phytosome technology.

\begin{tabular}{|c|c|c|c|c|c|c|c|}
\hline $\begin{array}{l}\text { Formulations } \\
\text { / Phytosomal } \\
\text { complex }\end{array}$ & $\begin{array}{l}\text { Active } \\
\text { principle/ } \\
\text { secondary } \\
\text { metabolites } \\
\text { from plant } \\
\text { drugs }\end{array}$ & Pharmacokinetics & Pharmacology & $\begin{array}{l}\text { Method of } \\
\text { preparation }\end{array}$ & Dose & $\begin{array}{c}\text { Route of } \\
\text { administration }\end{array}$ & Ref \\
\hline $\begin{array}{l}\text { Ginkgo biloba } \\
\text { Phytosomes }\end{array}$ & Flavonoids & $\begin{array}{l}\text { Flavonoids of } \\
\text { GBP stabilize the } \\
\text { Reactive oxygen } \\
\text { species }\end{array}$ & $\begin{array}{l}\text { Cardio- } \\
\text { protective, } \\
\text { antioxidant }\end{array}$ & $\begin{array}{l}\text { Phospholipids } \\
\text { complexation }\end{array}$ & $\begin{array}{l}100 \\
\mathrm{mg}\end{array}$ & Subcutaneous & 28 \\
\hline $\begin{array}{l}\text { Ginkgoselect } \\
\text { Phytosome }\end{array}$ & Flavonoids & $\begin{array}{l}\text { Inhibits lipid } \\
\text { peroxidation } \\
\text { stabilize the } \\
\text { Reactive oxygen } \\
\text { species }\end{array}$ & $\begin{array}{l}\text { Hepatoprotective, } \\
\text { antioxidant }\end{array}$ & $\begin{array}{l}\text { Phospholipids } \\
\text { complexation }\end{array}$ & $\begin{array}{l}25 \\
\text { and } \\
50 \\
\mathrm{mg} / \\
\mathrm{kg}\end{array}$ & Oral & 29 \\
\hline $\begin{array}{l}\text { Silybin } \\
\text { Phytosome }\end{array}$ & Flavonoids & $\begin{array}{l}\text { Absorption of } \\
\text { silybin phytosome } \\
\text { from silybin is } \\
\text { approximately } \\
\text { seven times greater }\end{array}$ & $\begin{array}{l}\text { Hepatoprotective, } \\
\text { antioxidant for } \\
\text { liver and skin }\end{array}$ & $\begin{array}{l}\text { Silybinphosph } \\
\text { olipid } \\
\text { complexation }\end{array}$ & $\begin{array}{l}120 \\
\mathrm{mg}\end{array}$ & Oral & 30 \\
\hline $\begin{array}{l}\text { Ginseng } \\
\text { Phytosome }\end{array}$ & Ginsenosides & $\begin{array}{l}\text { Increase } \\
\text { absorption }\end{array}$ & $\begin{array}{l}\text { Nutraceutical, } \\
\text { immunomodulato } \\
\mathrm{r}\end{array}$ & $\begin{array}{l}\text { Phospholipids } \\
\text { complexation }\end{array}$ & $\begin{array}{l}150 \\
\mathrm{mg}\end{array}$ & Oral & 31 \\
\hline $\begin{array}{l}\text { Green tea } \\
\text { Phytosome }\end{array}$ & $\begin{array}{l}\text { Epigallocatechi } \\
\mathrm{n}\end{array}$ & $\begin{array}{l}\text { Increase } \\
\text { absorption }\end{array}$ & $\begin{array}{l}\text { Nutraceutical, } \\
\text { antioxidant, } \\
\text { anticancer }\end{array}$ & $\begin{array}{l}\text { Phospholipids } \\
\text { complexation }\end{array}$ & $\begin{array}{l}50- \\
100 \\
\mathrm{mg}\end{array}$ & Oral & 31 \\
\hline $\begin{array}{l}\text { Grape seed } \\
\text { Phytosome }\end{array}$ & Procyanidins & $\begin{array}{l}\text { The blood TRAP } \\
\text { Total Radical- } \\
\text { trapping } \\
\text { Antioxidant } \\
\text { Parameter) were } \\
\text { significantly } \\
\text { elevated over the } \\
\text { control }\end{array}$ & $\begin{array}{l}\text { antioxidant, } \\
\text { cardio-protective }\end{array}$ & $\begin{array}{l}\text { Phospholipids } \\
\text { complexation }\end{array}$ & $\begin{array}{l}50 \\
100 \\
m g\end{array}$ & Oral & 31 \\
\hline $\begin{array}{l}\text { Hawthorn } \\
\text { Phytosome }\end{array}$ & Flavonoids & $\begin{array}{l}\text { Increasetherapeuti } \\
\text { c efficacy }\end{array}$ & $\begin{array}{l}\text { Cardio- } \\
\text { protective, } \\
\text { antihypertensive }\end{array}$ & $\begin{array}{l}\text { Phospholipids } \\
\text { complexation }\end{array}$ & $\begin{array}{l}100 \\
\mathrm{mg}\end{array}$ & Oral & 31 \\
\hline $\begin{array}{l}\text { Quercetin } \\
\text { Phytosome }\end{array}$ & Quercetin & $\begin{array}{l}\text { Exerted better } \\
\text { therapeutic } \\
\text { efficacy }\end{array}$ & $\begin{array}{l}\text { Antioxidant, } \\
\text { anticancer }\end{array}$ & $\begin{array}{l}\text { Quercetin } \\
\text { phospholipid } \\
\text { complexation }\end{array}$ & - & Oral & 32 \\
\hline
\end{tabular}

Table 2: Marketed formulation based on phytosome technology

\begin{tabular}{|l|l|l|l|l|}
\hline Brand name & Active principle & Drug Delivery system & Company & Ref. \\
\hline Greenselect Phytosome & Polyphenols from green tea leaf & Phytosome & Indena & 32 \\
\hline Leucoselect Phytosome & Polyphenols from grape seed & Phytosome & Indena & 32 \\
\hline Virtiva Phytosome & bilobalide from Ginkgo biloba leaf & Phytosome & Indena & 32 \\
\hline Silymarin Phytosome & Silymarin from milk thistle seed & Phytosome & Indena & 32 \\
\hline Visnadex Phytosome & Visnadin from Ammi visnaga umbel & Phytosome & Indena & 32 \\
\hline
\end{tabular}


Advantages of phytosomes

Phytosomes are promising tiny spheres are gaining popularity for the delivery of phytoconstituents due to their following advantages:

- Phytosomes increase the absorption of active constituents from herbs and hence improve the bioavailability.

- Phytosomes enhances the solubility of bile to the chemical constituent, to facilitate the liver targeting.

- Dose requirement is also reduced by use of phytosomal drug delivery system because these carriers increase the drug absorption.

- Improved stability due to chemical bond formation between phtyoconstituents bifunctional chemical compound such as phosphatidylcholine molecule.

- Phytosomes are safe to use for transdermal drug delivery.

\section{Disadvantages of phytosomes}

Despites of several advantages of phytosomes some fatal disadvantages such as phospholipids (lecithin) can induce proliferation on MCF-7 breast cancer cell line has been reported ${ }^{33}$. A major disadvantage of phytosome is leaching of the phytoconstituents off the 'some' which reduces the desired drug concentration indicating their unstable nature ${ }^{34}$.

\section{Phytosomes containing dosage forms}

Phytosome preparations can be administered by both routes as orally and topically, but to obtain the best result regarding bioavailability of formulation, it is

\section{REFERENCES}

1 Kokate C K, Purohit A. P and Gokhal S. B. Pharmacognosy $30^{\text {th }}$ ed. Pune: Nirali Prakashan; 2006.

2 Bombardelli E, Curris B and Della LR, Complexes between phospholipids and vegetal derivatives of biological interest, Fitoterapia 1989, 90(1):1-9.

3 Gupta A, Ashawat MS, Saraf S, Phytosome: A novel approach towards functional cosmetics, J Plant Sci 2007; 2(6):644-649.

4 Cott J, Natural Product Formulation, Available in Europe for Psychotropic Indications; Psychotropic Indications, Psychopharmacol Bull 1995, 31:745.

5 Parris K, Kathleen H, A review of bioavailability and clinical efficacy of milk thistle phytosome: a silybinphosphatidylcholine complex, Altern Med Rev 2005; 10(3):193-203.

6 Manach C, Scalbert A, Morand C, Polyphenols: Food source and bioavailability, Am J Clin Nutr 2004; 79:727-747.

7 Bhattacharya S, Phytosomes: Emerging strategy in delivery of herbal drugs and nutraceuticals, Pharma Times 2009; 41(3):8-12.

8 Mascarella S, Therapeutic and antilipoperoxidant effects of silybin-phosphatidylcholine complex in chronic liver disease, Preliminary results, Curr Ther. Res 1993; 53(1):98-102.

9 Franco PG, Bombardelli E, Complex compounds of bioflavonoids with phospholipids, their preparation and use and pharmaceutical and cosmetic composition containing them 1998, U.S. Patent No. EPO 275005.

10 Bombardelli E, Spelta M, Phospholipid-polyphenol complexes: A new concept in skin care ingredients, Cosm and Toil 1991; 106:69-76. important to study the dissolution and disintegration time of dosage forms while some of the examples of dosage forms containing phytosomes are given below ${ }^{35}$ :

Soft gelatin capsules: Indena recommend a granulometry of $100 \%<200 \mu \mathrm{m}$ in the suspension form vegetable or semi-synthetic oils can be used for this purpose.

Hard gelatin capsules: Usually not more than $300 \mathrm{mg}$ in a size 0 capsule, without precomresion method is used to fill the hard gelatins.

Tablets: Dry granulation represents the ideal manufacturing process to obtain tablets with higher unitary doses. Wet granulation is avoided due to adverse effect on phospholipid complex.

Topical dosage forms: The emulsion is used for this purpose to obtain the best result from phospholipid complex.

\section{CONCLUSION}

Phytosome technology connects both pharmacokinetics and pharmacology of the drug which help in better absorption of herbal drug extracts in comparison to other traditional dosage forms. Phytosomes offer the best bioavailability to the different classes of phytoconstituents such as flavonoids, aglycon glycosides and terpenoids through the skin and GIT. It also improves the intrinsic stability of neutraceuticals. So it can be concluded that phytosome is the best tool to enhance the absorption of phytoconstituents without any adverse drug effect.

11 Bombardellli E, Giuseppe M, bilobalide phospholipid complex, their uses and formulation containing them,1991, U.S. Patent No. EPO 275005.

12 Tripathy S, Patel D, Barob L, Naira S. A review on phytosomes, their characterization, advancement \& potential for transdermal application. Journal of Drug Delivery and Therapeutics, 2013; 3(3):147-152. doi:10.22270/jddt.v3i3.508

13 A Singh et. al, IJPS Autumn 2011; 7(4):209-219.

14 Kareparamban et. al, IJRPC 2012; 2(2).

15 Gupta A, Ashawat MS, Saraf S, Phytosome: A novel approach towards functional cosmetics, J Plant Sci 2007, 2(6), 644-649.

16 Cott J, Natural Product Formulation, Available in Europe for Psychotropic Indications; Psychotropic Indications, Psychopharmacol Bull 1995; (31):745.

17 Gabetta B, Zini GF, Pifferi G, Spectroscopic Studies on Idb1016 A New Flavanolignan Complex, Plant Med 1989; (55):615.

18 Malandrino S, Pifferi G, Idb-1016 Silybin Phosphatidylcholine Complex, Drugs Future 1990; (15):226227.

19 R. M. Facino, M. Carini, G. Aldini, Free radicals sea action and anti-enzyme activities of procyanidines vitis vinifera-a mechanism for their capillary protection. Arzneim. Forsch, 1994; (44):592-601.

20 Liposomes, A Practical Approach, Preparation of liposomes and size determination, New RRC, Oxford University Press, 1990; 36-39.

21 GMM Maghra by El,A. C. Williams. W. Barry, Oestradiol skin delivery fromultrade form ableliposomes: 
refinementofsurfactantconcentration, Int.J.Pharm, 2000; (196):63-74.

22 Fry DW, White JC, Goldman ID, Rapid Sectretion of Low Molecular Weight Solute from Liposomes without dilution, Anal Biochem 1978; (90):809-815.

23 Cevc G, Schatzlein A, Transdermal Drug Carriers: Basic Properties, Optimization and Transfer Efficiency in Case of Epicutaneously Applied Peptides, J. Control Release 1995; (36):3-16.

24 GMM Maghra by E, Williams AC, Barry BW, Oestrodiol Skin Delivery From Ultra deformable Liposomes: Refinement of Surfactant Concentration, Int J.Pharm 2000; (196):63-74.

25 Dayan N, Touitou E, Carrier for skin Delivery of Trihexyphenidyl HCl: Ethosomes v/s liposomes biomaterials 2002; (21):1879-1885.

26 Gabetta B, Zini GF, Pifferi G, Spectroscopic Studies on Idb1016A New Flavanolignan Complex, Plant Med 1989; (55):615.

27 BAIV Berge, VAB Wartzendruber, Geest J, Development of an Optimal Protocol for Ultrastructural Examination of Skin By TEM, J.Micros 1997; (187):125-133.
28 Vandana SP, Suresh RN, Exp Toxicol Pathol 2008; (60):397404.

29 Suresh RN, Vandana SP, Fitoterapia, 2008; (79):439-45.

30 Yanyu X, Yunmei S, Zhipeng C, Quineng P, Int J Pharm 2006, 307(1), 77-82.

31 Bhattacharya S, Pharma Times 2009, 41(3), 9-12.

32 Maiti K, Mukherjee K, Gantait A, Ahamed HN, Saha BP, Mukherjee PK. Iran J Pharmacol Ther 2005; (4):84-90.

33 Yamila B. Gándola, Sebastián E Pérez, Pablo E. Irene, Ana I Sotelo, Johanna G. Miquet, Gerardo R. Corradi, Adriana M. Carlucci, and Lorena Gonzalez1, Mitogenic effects of phosphatidylcholine nanoparticles on MCF-7 breast cancer cells. Biomed Res. Int. 2014.

34 Chivte P, Pardhi V, Joshi V, Ajitha RR, A review on therapeutic applications of phytosomes, Journal of Drug Delivery and Therapeutics. 2017; 7(5):17-21. doi:10.22270/jddt.v7i5.1513

35 Sanjay Saha et. al, Phytosome: A Brief Overview Scholars Academic Journal of Pharmacy Sch. Acad. J. Pharm, 2013; 2(1):12- 2 